\title{
Reconsidering trade and investment-led growth hypothesis: New evidence from Nigerian economy
}

\section{Orhan Çoban}

Department of Economics, Selçuk University,

Turkey

ocoban@selcuk.edu.tr

ORCID 0000-0001-6137-8937

\section{Stephen Taiwo Onifade}

Department of Economics, Selcuk. University,

Turkey

stephentaiwo.onifade@lisansustu.selcuk.edu.tr

ORCID 0000-0003-1497-7835

\author{
Abdul-Razak Bawa Yussif \\ Department of Economics, Selçuk. University, \\ Turkey \\ abdulrazak.bawa@,lisansustu.selcuk.edu.tr
}

\author{
Ilham Haouas \\ Department of Business and Finance, Abu Dhabi University, \\ United Arab Emirates \\ haonas.ilham@gmail.com
}

Abstract. The need to revisit the trade and investment-led growth hypothesis in the case of Nigerian economy has become pertinent following the recent record drop of $15 \%$ in FDI inflows to West Africa. This fall in FDI flow to the region has been primarily attributed to the abysmal performance of Nigeria in attracting FDI as the largest economy in the sub-region despite an average rise in the rate of FDI flow to Africa as a continent at large. In this study, the trade and foreign direct investment-led growth hypothesis were revisited in the case of Nigerian economy. Our empirical findings provide evidence to support the trade-led growth

Received: January, 2020 1st Revision:

May, 2020

Accepted:

September, 2020

DOI:

10.14254/2071 $8330.2020 / 13-3 / 7$ 
under review. Thus, to harness the inherent benefits of inward FDI in the wake of dynamic trade relations, efficacious policy directions were provided with respect to the findings.

Keywords: Nigeria, trade, inward FDI, export-led growth, domestic investments, bound test.

JEL Classification: F10, C50, E22

\section{INTRODUCTION}

Trade and investment policies have always been dynamic concepts that have witnessed diverse significant periodical changes across various economies around the globe. Despite the magnitude of the existing research on trade and investment vis-à-vis qualitative and quantitative approaches, the impacts of trade and investment on economic growth can be considered as yet a debatable matter. What works for growth may vary from one economy to another, even when it is widely held by many that trade and investment are vitally important determinants of economic growth, especially in developing countries (Greenaway et al., 2002; Asiedu, 2002).

The assertion that promotes positive sentiments towards the impacts of international trade on economic growth has an age-long history that is traceable to some early classical economists. Adam Smith (1776) identified the importance of the mechanism through which invisible hands of the market interact to create a competitive free trading system, thereby culminating in the rise of the earliest classical theories in international trade since the eighteenth century (Hutchison, 1976). David Ricardo (1817), another famous classical economist, also emphasized on the importance of free trade as a tool for augmenting the average standard of living and the general wealth of all participating trading nations in his theory of comparative advantage. This theory thrived on the assumption of international immobility of the factor inputs vis-à-vis capital and labor, absence of externalities, assumption of static gains, and the existence of trade balancing adjustment mechanism such that international trade works as a bartering process among other factors. The Ricardian proposition received numerous criticisms as to its practicability and unrealistic assumptions, thus making the arguments in support of trade liberalization questionable. Broadly speaking, healthy competition is one major key to ensuring better welfare, however, there may be a situation where attaining higher welfare level can become a mirage when there is an extreme protectionist regime with massive implementation of tariffs on imports to discourage imported goods while subsidies are given for local goods (Krugman, 1987). There are substantial pieces of evidence in many recent studies to support the view that trade liberalization creates great net gains for participating economies, while there are also arguments for the contrary (Melitz \& Trefler, 2012; Estevadeordal \& Taylor, 2013; Dix-Carneiro \& Kovak, 2017).

In the 1960s, the subject matter was dominated by the arguments in support of trade protectionism. Trade policies were designed to promote import substitution with the fundamental focus on protecting the infant industries, especially in developing economies against some drawbacks of international trade which were well articulated by Rual Prebisch (1950) while identifying numerous general problems faced by Latin American countries. Furthermore, he argued that primary commodities should be exchanged for capital goods which are necessary for triggering economic growth and such growth should not be carried out at the expense of an ideal foreign trade, but rather countries should know how to create their own benefits from the growing volume of international trade. Rodrik (1997) argued that most of developing economies are primary sector driven and as a result, volatilities in international prices for primary goods are often associated with vulnerabilities to external shocks. In addition to this, Alesina \& Perotti (1997) also argued that the welfare responsibility of the government can be distorted or limited by the exposure to competition 
from foreign economies due to openness to international trade. In consequence, governments often intervene to protect their infant businesses from real or perceived unhealthy foreign competitions by developing trade policies that place some kinds of restrictions on imports.

Towards the end of the twentieth century and the early twenty-first century, especially following the global financial crisis in 2008, the trade paradox in times of globalization started witnessing a renewed remarkable change but this time around with much attention given to foreign direct investment (FDI) as a key to economic growth amidst changing trade relations among countries. The concerns about the cost of protectionism which may eventually outweigh the benefits from trade liberalization combined with other factors helped to partly stem the global rise in protectionism, especially with regards to the dichotomy between developed and developing economies (Kee et al., 2013). Consequently, policymakers are confronted with the task of designing effective and balanced trade policies while attracting FDI inflow since the two variables are interconnected and important in galvanizing economic growth, especially in developing countries (Aizenman \& Noy, 2006; Zahonogo, 2016). Rodrik (2018) observed that there is widespread consensus on the superiority of free trade to trade protectionism, however, he also argues further that the current trade agreement encompasses factors like investment among other issues. We, therefore, want to re-examine the trade and investment-led growth nexus in the case of Nigerian economy within the scope of this country's current economic realities.

\section{LITERATURE REVIEW}

\subsection{Synopsis of Global Trade and Foreign Direct Investment in Relation to the Nigerian Economy}

On the international stratum, the ratio of trade growth to GDP averaged at about $1.0 \%$ in the years succeeding the 2008 global financial crisis but as of 2017, that figure has risen remarkably to an average of 1.5\% (WTO, 2018). This significant rise in the ratio of global trade growth to the world's GDP growth strengthens the relevance of trade in driving economic growth and development on the international level. On a continental and regional basis, it is reported that Africa's share of merchandise exports to the international performances has nearly doubled in 2017 to about $19.6 \%$ from $10.3 \%$ of total export value in 2010 (WTO, 2018).

In the case of Nigeria, the total of exports and imports of goods and services measured as a share of gross domestic product between 2010 and 2015 averaged at about 40.4\%. However; as at the end of 2016, this figure has drastically dropped by about $48.7 \%$ thereby culminating the economic recession that the country witnessed in the second quarter of 2016 as evident by the $-1.62 \%$ annual GDP growth in the same year (WDI, 2018).

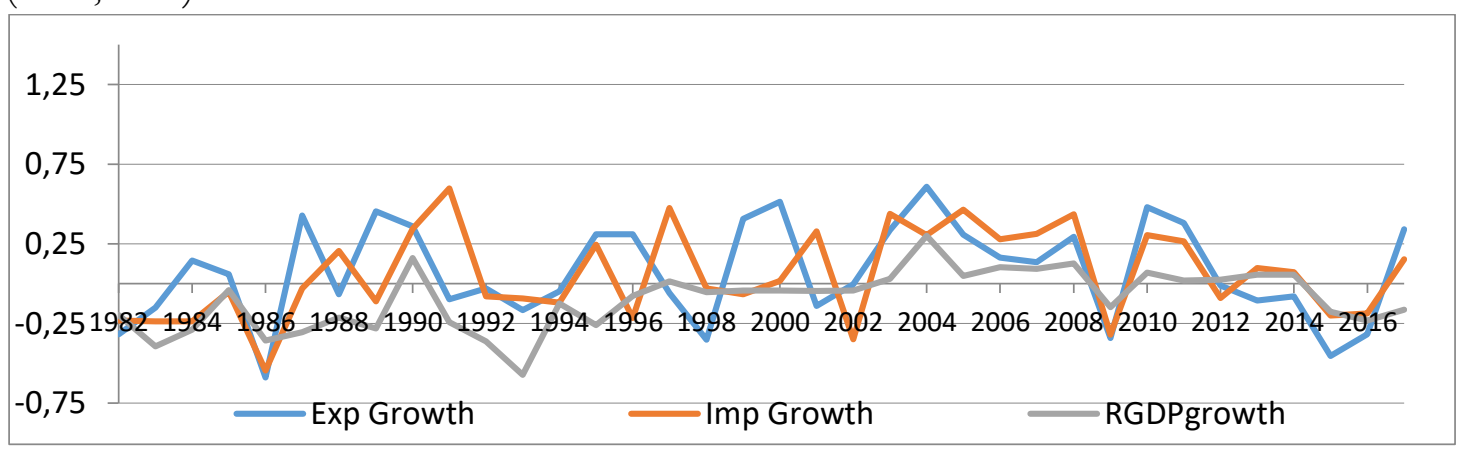

Figure 2.1. Trade and real GDP growth in Nigeria, 1982-2017

Source: Author's computation using WDI (2018) data 
The country's trade performances, however, started to witness some improvements as the nation slowly recovers from the economic recession thereby putting the country back to a growth path with about $0.80 \%$ growth rate while trade to GDP ratio stood at about $26.34 \%$ as at the last quarter of the year 2017 .

On the aspect of investment with a specific focus on foreign direct investment (FDI), the statistics from the nation has not been impressive based on various developments in recent years despite the $11 \%$ rise in FDI flows to Africa as a continent and 2\% rise in the flows to developing economies on a global level as reported by United Nations Conference on Trade and Development (UNCTAD, 2019). The net inflow of foreign direct investment as a percentage of GDP in Nigeria witnessed a significant rise between the early 1980s and 1994 with the figures standing at an average rate of about $1.8 \%$ over this period. However, this rate has witnessed a steady decline from the mid-1990s with more downward trends especially in the years following the global financial crisis of 2008. Between 2012 and 2017 for instance, FDI inflow constituted less than $1 \%$ of the GDP on the average as reflected in figure 2.2.

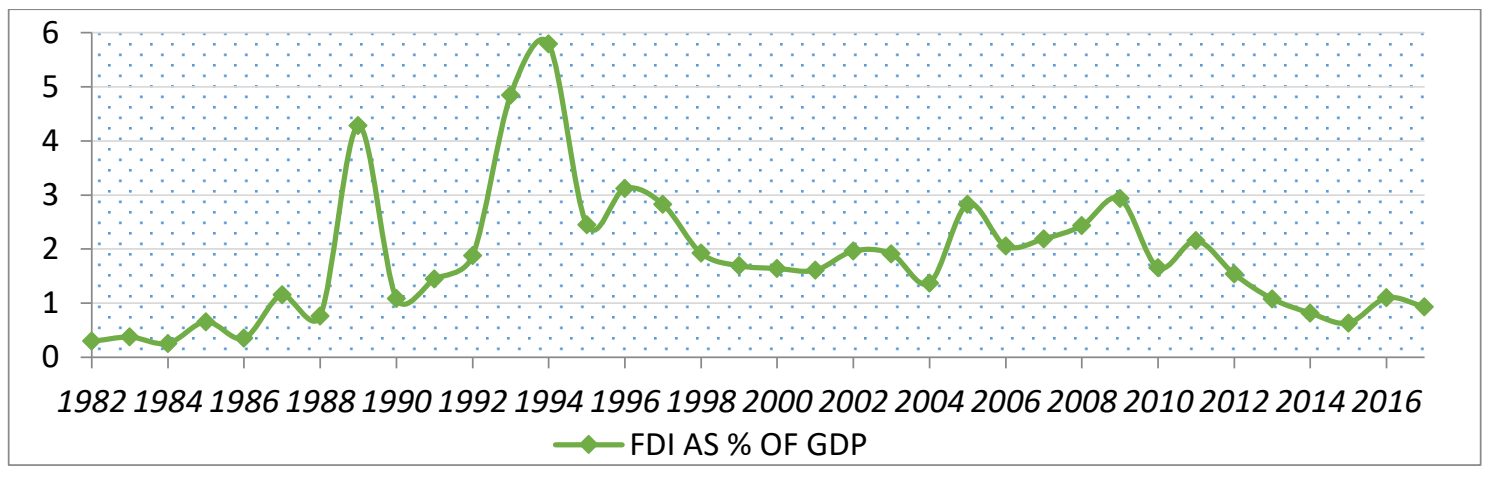

Figure 2.2. FDI as \% of GDP in Nigeria, 1982-2017

Source: Author's computation using WDI (2018) data.

This sharp decline can be attributed to various factors that are linkable to the global revolution in foreign investment decisions as investors seek more relatively stable economic and political climes to invest. Despite the huge advantages the country has in terms of abundant natural and human resources coupled with large market size which naturally should have given Nigeria an edge in FDI attraction in Africa, however, the nation is yet to demonstrate an adequate capacity to attract FDI in terms of necessary infrastructures and investment policies that are expected to promote ease of doing business. FDI flows to Nigeria fell drastically by $21 \%$ to a total of $\$ 3.5$ billion in 2017 and this huge fall has consequently led to an $11 \%$ decline in the total FDI inflow to the entire West African economy. By 2018, there was about a $\$ 9.6$ billion decline in FDI inflow to West Africa translating to about a 15\% drop in FDI flows to the sub-region compared to the $11 \%$ decline that was recorded in the previous year. This sharp fall in FDI inflow to West Africa has been largely attributed to the depression in the Nigerian economy in 2016 and has created a ripple effect over the following two consecutive years (UNCTAD, 2019).

\subsection{Empirical literature review}

Trade and investment discourse have attracted substantial attention by researchers on a global level and Nigeria as a nation has not been left out of the discussions so far. The available empirical shreds of evidence on trade and investment with respect to economic growth in Nigeria are replete with mixed results. To begin with the trade and economic growth nexus, Ekpo (1995) obtained an inverse relationship between openness to trade and economic growth in Nigeria within a period of 23 years starting from 1970 to 1992. Oladipo (1998) while estimating the degree of relationship between openness to trade and growth in Nigeria 
applied quarterly data spanning from 1970 to 1996 with export to GDP ratio and trade to GDP ratio as proxies for trade openness. He obtained a positive correlation in the former but on the contrary, the later proxy produced a negative result. In a different work, Omolola (1998) also examined the long-run relationship between trade openness and growth and came up with the findings that there is no significant long-run relationship between economic growth and ratio of total trade to GDP as a proxy for trade openness in the case of Nigeria. A contrary result to Omolola (1998) came up from the findings of Olufemi (2004) having obtained a uni-directional relationship from a causality test between openness and economic growth. Going by these extant studies, there is no doubt that the literature is divided based on empirical evidence of how trade impacts economic growth in the case of Nigeria.

The available empirical evidence on investment with respect to FDI and economic growth in Nigeria have also shown mixed results. The findings of Akinlo (2003) showed that the impact of FDI on SubSaharan African countries as a whole is positive. However, Olokoyo (2012) while examining the links between FDI and economic growth in the specific case of Nigeria; applied the Ordinary Least Squares (OLS) methodology on some sample data from the country and the result suggested that FDI is insignificant to real economic growth in Nigeria. It is worthy to note that there may be some limitations to the robustness of the findings arising from the choice of methodology for the study. There are issues bothering on nature of the data set in terms of their statistical properties if the OLS methodology is to be applied directly. Furthermore, there is a limitation on the scope of the results since we do not clearly have insight into the nature of the relationship between FDI and growth concerning the short-run and long-run dynamics. Olatunji and Shahid (2015) maintained that there is a positive dynamic relationship between FDI and economic growth in Nigeria but only in the short run since their Engle \& Granger co-integration analysis result suggested no long-run relationship. Furthermore, it is also important to note that a substantial proportion of the extant studies have examined the trade and investment-led growth hypothesis implicitly. Some studies have focused mainly on aggregated trade openness measures whereas the country is a primary commodity export-driven economy, while others have also focused mainly on the FDI thereby omitting the relevance of the export-led growth hypothesis and domestic investment in the entire interplay respectively. Thus, this study specifically seeks to provide a comprehensive investigation of the trade and investment-led growth hypothesis for the case of Nigeria by incorporating the domestic investment component while expanding the trade component beyond the traditional openness proxy to include an isolated export component. Shrestha and Bhatta (2018) emphasized the significance of caution in the selection of proper methodological approaches especially when time-series data are to be utilized in an empirical analysis. In this regard, the intended methodology that was adopted in this study also serves as a panacea to some of the aforementioned methodological shortfalls in the extant studies.

\section{DATA AND METHODOLOGY}

The autoregressive distributed lag model (ARDL) approach of Pesaran et al. (2001) was applied to carry out the empirical analysis in this study. Annual time-series data from 1982 to 2017 were sourced from the World Bank development indicators (WDI, 2018) for all the variables that were used for the empirical analysis in the study. The simplest representational form of the relationship in this study is provided in equation (1) as follows:

$$
\mathrm{RGDPG}=\alpha_{0}+\alpha_{1} \mathrm{OPEN}+\alpha_{2} \mathrm{EXPG}+\alpha_{3} \text { FDI }+\alpha_{4} \mathrm{DINVS}+\mu_{\mathrm{t}}
$$

From equation (1) above, RGDPG represents the economic growth as measured by the annual percentage growth of the real gross domestic product. FDI denotes the net inflow of foreign direct 
investment into the country over the period of study while OPEN denotes trade openness ratio which is popularly measured by the sum of export and import as a ratio of the GDP. Gross capital formation (GDINS) and the annual percentage growth of export (EXPG) were also incorporated into the model to factor in the impacts of domestic investment and to further investigate the export-led growth hypothesis respectively.

\subsection{Unit Root Test}

One of the fundamental preconditions upon which empirical analyses are carried out with time series data is the stationarity assumption about the data set. Time series data are a collection of random variables at given point in time and they are generally seen to be stationary if the mean and variance are constant over time and the value of the covariance does not depend on the actual time in which they are computed (Box et al. 2015). Two major approaches were followed to conduct the unit root test for the variables following some contemporary studies (Haseeb et al., 2018; Asongu et al., 2019; Onıfade et al., 2020a). Firstly, we applied the Augmented Dickey-Fuller (ADF, 1981) approach to test for the unit root as follows:

$$
\Delta Y_{t}=\alpha+\delta Y_{t-1}+\sum_{i=1}^{p} \gamma_{i} \Delta Y_{t-i}+\varepsilon_{t}
$$

Equation (2) above shows a general ADF equation for unit root test for a time series variable $Y_{t}$ where; $\Delta Y_{t}=Y_{t}-Y_{(t-1)}$ and this represents the first difference of the $Y_{t}$ series. To consolidate the conclusions about the unit root test results from equation (2) above as these tests are very important for the choice of our methodology in the empirical analysis, a non-parametric test was also carried out on all the variables with the Philips-Perron (PP, 1988) test.

$$
\Delta Y_{t}=\delta Y_{t-1}+\gamma_{i} D T_{t-i}+\mu_{t}
$$

Equation (3) above represents a general functional expression to carry out the (PP) test for a variable, say variable $\mathrm{Y}$. Where $\mathrm{DT}_{(\mathrm{t}-\mathrm{i})}$ denotes the deterministic trend and $\mu_{\mathrm{t}}$ is stationary at level. The null hypothesis was tested for $\delta=0$ against the alternative that $\delta<0$ in Equation (2) \& (3). The PP test was conducted as an alternative check on the initial findings from the ADF results to further control for possible cases of autocorrelation and heteroskedasticity in the data. It is, however, important to note that the unit root test results were similar in both approaches for all variables and the results are presented in Table 1.

Table 1

\begin{tabular}{|c|c|c|c|c|c|}
\hline \multirow[b]{3}{*}{ VARIABLES } & \multicolumn{4}{|c|}{ Levels } & \multirow[b]{3}{*}{ CONCLUSION } \\
\hline & \multicolumn{2}{|c|}{ ADF } & \multicolumn{2}{|c|}{ PP } & \\
\hline & Intercept & Trend \& & Intercept & Trend \& & \\
\hline OPEN & 0.3008 & 0.9063 & 0.3615 & 0.6428 & \\
\hline EXPG & $0.0000^{* * *}$ & $0.0000^{* * *}$ & $0.0000^{* * *}$ & $0.0000^{* * *}$ & $\mathrm{I}(0)$ \\
\hline FDI & 0.5355 & 0.6429 & 0.5174 & 0.5094 & \\
\hline GDINS & 0.5240 & 0.1889 & 0.5647 & 0.1065 & \\
\hline RGDPG & $0.0158^{* * *}$ & $0.0150^{* * *}$ & $0.0203^{* *}$ & $0.0150^{* * *}$ & $\mathrm{I}(0)$ \\
\hline \multicolumn{6}{|c|}{ First Difference } \\
\hline$\Delta(\mathrm{OPEN})$ & $0.0000 * * *$ & $0.0000 * * *$ & $0.0000 * * *$ & $0.0000 * * *$ & I (1) \\
\hline$\Delta(\mathrm{EXPG})$ & $0.0000 * * *$ & $0.0000 * * *$ & $0.0001 * * *$ & $0.0000 * * *$ & \\
\hline$\Delta(\mathrm{FDI})$ & $0.0000 * * *$ & $0.0000 * * *$ & $0.0000 * * *$ & $0.0000 * * *$ & I (1) \\
\hline$\Delta$ (GDINS) & $0.0001 * * *$ & $0.0013 * * *$ & $0.0000 * * *$ & $0.0002 * * *$ & $\mathrm{I}(1)$ \\
\hline$\Delta($ RGDPG $)$ & $0.0000 * * *$ & $0.0000 * * *$ & $0.0000 * * *$ & $0.0000 * * *$ & \\
\hline
\end{tabular}

Unit Root Test Results 
The ADF and PP tests were used to perform the unit root test given two model specifications ranging from the general specification that captures effects of trend and intercept term to the restricted model with intercept only (Enders, 1995). ${ }^{* *}$, represents the rejection of the null hypothesis of the presence of unit root at a $1 \%$ level of significance, while ${ }^{* *}$ and ${ }^{*}$ represent the rejection of the null hypothesis at $5 \%$ and $10 \%$ levels respectively.

The unit root test results as shown in table 1 reveal that our variables of interest have mixed order of integration and all variables are at most stationary at first difference. This implies that we do not have any I(2) variables in our model. It is important to know that the choice of ARDL method in this study is justified by the nature of our variables based on the unit root test results and other inherent advantages from the application of this methodology as seen in contemporary literature (Bölük \& Mert, 2015; Nwaka \& Onifade, 2015; Taiwo et al., 2020). Engle and Granger (1986) have shown that regressing non-stationary time series that possess long-run relationship on another will generate a stationary stochastic error. This consequently implies that time-series data may not have equilibrium properties in the short run but they may possess equilibrium relationships in the long run and as such, they are said to be cointegrated. A cointegration test was therefore conducted to ascertain the existence of a long-run equilibrium relationship among our variables of interest. Shrestha and Bhatta (2018) and Onifade et al., (2020b) have noted that the Johansen cointegration test cannot be applied directly in the situation where variables have mixed order of integration as in the case of our data in this study but rather; when all variables are integrated of order one, I(1). They further maintained that an autoregressive distributed lag (ARDL) model is applicable in cases where timeseries data possess a mixed order of integration. Hence the bound test approach to cointegration as developed by Pesaran and Shin (1998) and extended by Pesaran et al. (2001) was applied to test for longrun equilibrium among the variables.

\subsection{ARDL bound test approach to cointegration}

Pesaran et al. (2001) noted some of the basic advantages of the ARDL model in its application to include; its flexible nature since it does not require all variables to be I(1), the compatibility with endogenous nature of variables in a vector autoregressive (VAR) models and the possibility of obtaining short-run and long-run coefficients simultaneously. We specify the conditional ARDL ( $\left.\mathrm{p}, \mathrm{q}_{1}, \mathrm{q}_{2}\right)$ in the following equations:

$$
\begin{aligned}
& \Delta R G D P G_{t}=c_{0}+\sum_{i=1}^{p} \alpha_{1} \Delta R G D P G_{t-i}+\sum_{i=1}^{p} \alpha_{2} \Delta O P E N_{t-i}+\sum_{i=1}^{p} \alpha_{3} \Delta E X P G_{t-i}+\sum_{i=0}^{p} \alpha_{4} \Delta F D I_{t-i} \\
& \quad+\sum_{i=1}^{p} \alpha_{5} \Delta G D I N S_{t-i}+\beta_{1} R G D P G_{t-1}+\beta_{2} O P E N_{t-1}+\beta_{3} E X P G_{t-1}+\beta_{4} F D I_{t-1} \\
& \quad+\beta_{5} G I N S_{t-1}+\varepsilon_{t}
\end{aligned}
$$

The cointegration test model is given in equation (4) above where $\mathrm{p}$ is the maximum lag for the models, $\Delta$ denotes the difference operator, $i$ represent the appropriate lag length as selected by the Akaike information criterion (AIC) for the $\operatorname{ARDL}(1,1,1,0,1)$ and all the variables in the models remain as previously defined. The mean of the error term $\varepsilon_{t}$ as given in the equation is assumed to be zero without serial correlation. The null hypothesis $\left(\mathrm{H}_{0}\right)$ of an absence of a long-run equilibrium among the variables will be tested against an alternative hypothesis $\left(\mathrm{H}_{1}\right)$ that is defined as the presence of long-run equilibrium relationship among variables in each of the models:

$$
\begin{aligned}
& \mathrm{H}_{0}: \beta_{1}=\beta_{2}=\beta_{3}=\beta_{4}=\beta_{5}=0 \\
& \mathrm{H}_{1}: \beta_{1} \neq \beta_{2} \neq \beta_{3} \neq \beta_{4} \neq \beta_{5} \neq 0
\end{aligned}
$$

The calculated $\mathrm{F}$ statistics from the estimated model will be used to carry out the above joint test based on the computed critical values for the ARDL bound test as provided by Pesaran et al. (2001). Subsequently, 
the error correction model that is associated with the long-run relationship was formulated as specified in equation 5 below:

$$
\begin{aligned}
\Delta R G D P G_{t}=c_{0} & +\sum_{i=1}^{p} \alpha_{1} \Delta R G D P G_{t-i}+\sum_{i=1}^{p} \alpha_{2} \Delta O P E N_{t-i}+\sum_{i=1}^{p} \alpha_{3} \Delta E X P G_{t-i}+\sum_{i=0}^{p} \alpha_{4} \Delta F D I_{t-i} \\
& +\sum_{i=1}^{p} \alpha_{5} \Delta G D I N S_{t-i}+\vartheta E C T_{t-1}+\mu_{t}
\end{aligned}
$$

From equation 5 above, the ECT variable represents the error correction term and the estimated $\vartheta$ coefficient is expected to measure the speed of adjustment in the long run interaction among the variables. In cogent terms, the ECT variable shows how fast the short run disequilibrium properties will adjust to the long-run equilibrium conditions.

\section{EMPIRICAL RESULTS AND DISCUSSION}

The results of all other analyses have been reported in various tables starting with the bound test results as given in Table 2 .

Table 2

Bound Test Results

\begin{tabular}{|l|l|l|l|}
\hline Equations & Lags (AIC) & \multicolumn{1}{|l|}{ F-Statistics } & Decision \\
\hline $\mathbf{( 4 )}$ & 1 & $7.18^{* * *}$ & Cointegration \\
\hline $\begin{array}{l}\text { Critical Values } \\
\text { (F-Statistics) }\end{array}$ & Lower bound at 5\%=2.56 & Upper bound at $1 \%=3.49$ \\
\hline
\end{tabular}

Source: Authors' results. *** indicates significance level at a $1 \%$ level.

From the bound test results in table 2 above, the null hypothesis of no levels relationship can be rejected in equation 4 given that the estimated F-statistics is higher than the critical values of the upper bound F-statistics at the conventional significance level of 5\%. Thus, it is clear that there is a long-run relationship between the variables. Following the establishment of this long-run relationship among the variables, we proceeded to obtain the long-run coefficients and the estimates are presented in Table 3.

Table 3

Long-run Coefficients

\begin{tabular}{|l|l|l|l|}
\hline Variables & Coefficients & t-statistics & P-Values \\
\hline C & -0.4325 & $-3.2854^{* * *}$ & 0.0029 \\
\hline OPEN & 0.3644 & $1.9705^{*}$ & 0.0595 \\
\hline EXPG & 0.0120 & $1.8032^{*}$ & 0.0830 \\
\hline FDI & -0.0193 & -1.2099 & 0.2372 \\
\hline GDINS & 0.0048 & $2.3738^{* *}$ & 0.0253 \\
\hline
\end{tabular}

Source: Authors' results. All variables remained as earlier defined where OPEN represents Trade Openness, calculated as the sum of total imports and exports as a ratio of the GDP and EXPG denotes the annual percent growth in total export. FDI and GDINS represent foreign direct investment inflow and domestic investment respectively. The superscripts $* * *, * *$, and $*$ represent the statistical significance of estimates at $1 \%, 5 \%$, and $10 \%$ levels of significance respectively.

The results of the estimated long-run parameters for the study as provided in Table 3 above show that all the variables are statistically significant to the economic growth of the country except foreign direct 
investment (FDI). Both openness to international trade and expansion in export have significant positive impacts on real economic growth in Nigeria as a unit rise in trade openness and expansion in export is expected to increase growth rate by about 0.364 and 0.012 units respectively. This result buttresses the importance of trade relations in boosting economic growth and development while providing further evidence in support of the export-led growth hypothesis in the case of the Nigerian economy. Based on standard economic models, Sulaymonov (2017) has noted that free trade triggers various economic benefits thereby helping to increases national welfare. Our results may imply that the Nigerian economy stands to benefit more from a larger trade ratio in terms of real economic growth, however, while we acknowledge the possible numerous benefits from trade, we should also note that Nigerian economy is a primary export commodity-driven economy and as such expansion in the volume of trade vis-à-vis the nation's major export commodities like petroleum and agricultural products is expected to aid the growth of the economy. Thus, to be able to guarantee sustainable growth from trade volumes, a concerted effort has to be made towards expanding the country's export base beyond the current focus on the export of primary commodities while also encouraging large scale domestic investment. The results further reveal that domestic investment demonstrates a significant positive impact on economic growth even when foreign direct investment (FDI) was found to be insignificant to the growth of the economy for the study. Typically speaking, FDI is expected to have a huge positive impact on driving economic growth especially in developing economies like Nigeria; however, numerous challenges surround the Nigerian investment environments. Such challenges include political instability as evident by unstable government policies, the incessant crisis in the labor market, and most importantly; infrastructural deficits among other issues. These challenges combined create huge impediments for both existing and potential investors in the country thereby translating to low investment returns while reducing the overall chances of FDI inflow to the country. In recent years many businesses have been closed down while some others have been forced to relocate their operations to other neighboring countries such as Ghana thereby undermining the desirable impacts of FDI on economic growth in the country. The estimates from the error correction model are provided in table 4.

Table 4

Error Correction Model

\begin{tabular}{|l|l|l|l|}
\hline Variables & Coefficients & t-statistics & P-Values \\
\hline$\Delta($ OPEN $)$ & -0.2067 & -1.1874 & 0.2458 \\
\hline$\Delta$ (EXPG) & 0.0017 & $2.9045^{* * *}$ & 0.0074 \\
\hline$\Delta$ (GDINS) & 0.0132 & $6.3932^{* * *}$ & 0.0000 \\
\hline ECT $(-1)$ & -0.9763 & $-7.1701^{* * *}$ & 0.0000 \\
\hline R $^{2}$ & 0.68 & \\
Adjusted R & & \\
F-statistic & 0.65 & & \\
DW-stat & 16.01 & & \\
P-Value & 1.79 & & \\
\hline
\end{tabular}

Source: Authors' results. The superscripts ***, **, and * represent the statistical significance of estimates at $1 \%, 5 \%$, and $10 \%$ levels of significance respectively. The symbol $\Delta$ denotes the difference operator while ECT represents the error correction term.

The coefficient of the error correction term (ECT) is negative 0.9763 and it is also found to be highly statistically significant. This shows that the existing disequilibrium among the variables will adjust at an average speed of about $97.6 \%$ per annum in the long-run. Both domestic investment and export were found to be significant to growth even in the short-run scenario. This has further reinforced the position of the 
export-led growth hypothesis even when aggregate trade informs of openness is found to be insignificant to economic growth in the short-run. On the overall, the explanatory power of the model can also be said to be satisfactory as the coefficient of determination $\left(\mathrm{R}^{2}\right)$ is reasonably high considering the fact that at least $65 \%$ of the variations in economic growth is explained by the model. In other to make more consolidations on our findings, we proceeded to explore the causal relationship among the variables by carrying out a Granger Causality Test, and the summary of the test is provided in Table 5.

Table 5

Granger Causality Test Results

\begin{tabular}{|l|c|c|c|c|c|c|}
\hline & \multicolumn{5}{|c|}{ F-Statistics } & DINS \\
\hline $\begin{array}{l}\text { Dependent } \\
\text { Variables }\end{array}$ & RGDPG & OPEN & EXPG & FDI & DECISION \\
\hline RGDPG & - & $3.91191^{* *}$ & 1.31655 & $3.17006^{*}$ & 0.55827 & $\begin{array}{l}\text { Open \& FDI } \\
\rightarrow \text { RGDP }\end{array}$ \\
\hline OPEN & 0.84688 & - & 0.10612 & 1.39858 & $7.77668^{* * *}$ & $\begin{array}{c}\text { DINS } \\
\rightarrow \text { OPEN }\end{array}$ \\
\hline EXPG & 0.97742 & 0.09214 & - & 0.34172 & 0.05335 & \\
\hline FDI & $3.92581^{* *}$ & 0.11095 & 0.04346 & - & 0.00281 & $\begin{array}{l}\text { RGDPG } \\
\rightarrow \text { FDI }\end{array}$ \\
\hline DINS & $14.8591^{* * *}$ & 1.03221 & 0.19096 & $50.8990^{* * *}$ & - & $\begin{array}{l}\text { RGDPG \& FDI } \\
\rightarrow \text { DINS }\end{array}$ \\
\hline
\end{tabular}

Source: Authors' results. The superscripts ${ }^{*}$, ${ }^{*}$, and ${ }^{* * *}$ represent the rejection level of no causality between variables at $10 \%, 5 \%$, and $1 \%$ levels of significance respectively. All the variables remain as earlier defined.

The Granger causality test results reveal the existence of unidirectional causality running from trade openness to economic growth of the country. On the other hand, the growth of the economy is found to be granger causing both foreign direct investment and domestic investment in the country while domestic investment uni-directionally granger causes trade openness. Finally, we subjected the model to all necessary diagnostic tests to ensure the statistical appropriateness and its overall suitability for policy directions. The serial correlation test and heteroscedasticity test were conducted to ensure that the residuals from the model are serially uncorrelated. In addition to that, the CUSUM Test was also carried out to see if our models are structurally stable. The diagnostic test results are provided in Table 6.

Table 6

Diagnostic Test

\begin{tabular}{|l|l|}
\hline Test Statistics & F-Stat (P-value) \\
\hline Breusch-Godfrey Serial Correlation LM Test: & $0.5368(0.4706)$ \\
\hline Breusch-Godfrey Test Heteroscedasticity & $0.4684(0.8671)$ \\
\hline Jarque-Bera Normality Test & $2.4235(0.2976)$ \\
\hline
\end{tabular}




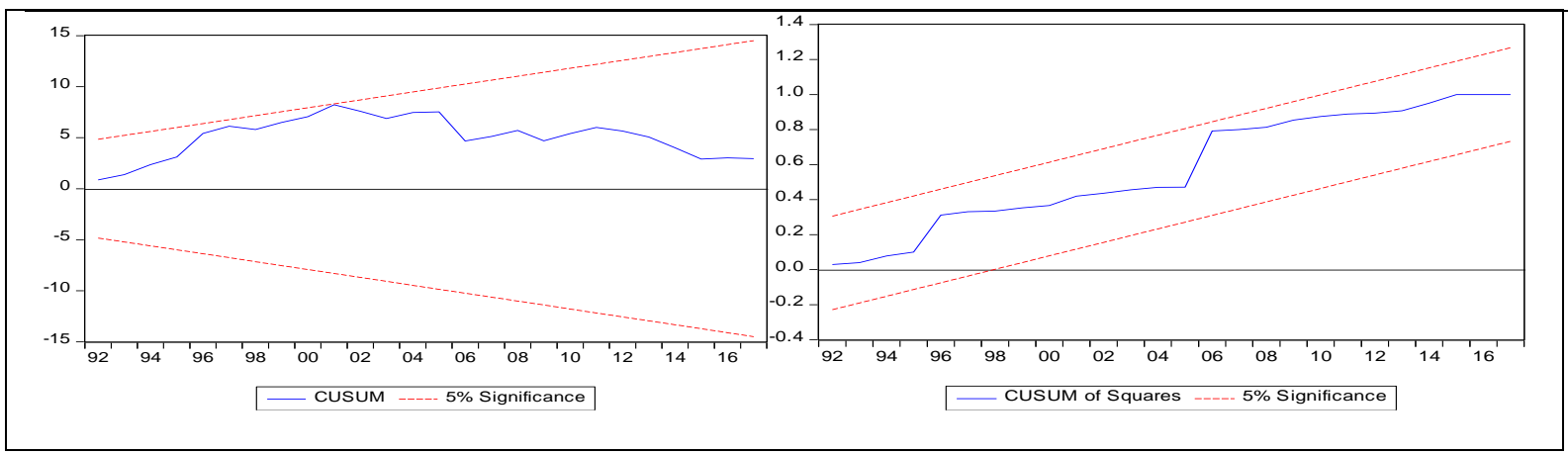

Source: Authors' results. Note: The models were found to have passed the necessary diagnostic tests. This implies that our models are not suffering from statistical shortfalls and as such, the model is suitable for policy direction.

\section{CONCLUSION AND RECOMMENDATIONS}

From the empirical analysis, both trade openness and export growth demonstrate a significant positive impact on real economic growth in Nigeria for the period under review. On the other hand, considering the investment side of the nexus, FDI shows no significant impact on real economic growth in Nigeria while domestic investment contributes significantly to growth in the country in both short-run and long-run scenarios. This situation is primarily as a result of the numerous challenges that surround the Nigerian investment environments. Some major challenges mitigating the Nigerian investment clime have been identified to include but not limited to political instability as evident by unstable government policies, the incessant crisis in the labor market, and infrastructural deficits. These factors together reduce the chances of FDI inflow to the country and consequently serve as obstacles to the potential contributions of FDI towards real economic growth of the nation. We, therefore, recommend that the government should come up with more policy initiatives that will help to position the Nigerian economy as a safe investment destination by addressing some of the aforementioned challenges to FDI inflow to the country.

In specific terms, trade and investment-related policy should be holistically designed. For instance, investment-friendly tax policies are needed to guide against possible issues of tax-driven fall in FDI while adequate priority is been given to the provision of basic infrastructural facilities such as stable electricity and transport facilities among others. In addition to this, it is time for the government to embark on aggressive diversification of the economy. The findings from this study show that export is very significant to the country's economic growth and we, therefore, call for conscious effort on the side of the government to diversify the economy, especially into a tech-based economy. By so doing, more FDI can be attracted to the IT sector which the country has a great potential to expand considering the huge market size and the teeming youth population. Improve technology will also go a long way in helping to enhance both agricultural and manufacturing sectors thereby boosting the nation's export base that is currently dominated by the export of raw primary products. Finally, holistic measures should also be taken to ensure that all public institutions are strengthened to ensure smoothness and transparency in business operations. The judiciary, for instance, needs to be strengthened to boost investors' confidence since there are legal implications to both local and international trade and investments.

\section{ACKNOWLEDGEMENT}

We would like to express our gratitude to the anonymous referees for their valuable comments and suggestions towards improving the quality of the article. 


\section{REFERENCES}

Aizenman, J., \& Noy, I. (2006). FDI and trade-Two-way linkages?. The Quarterly Review of Economics and Finance, 46(3), 317-337. https://doi.org/10.1016/j.qref.2006.02.004

Akinlo, E. (2003). Globalization, international investment and stock market growth in Sub Saharan Africa: final research report submitted to the Institute of Developing Economies, JETRO, Japan.

Alesina, A., \& Perotti, R. (1997). The Welfare State and Competitiveness. The American Economic Review, 921-939. doi:10.3386/w4810

Asiedu, E. (2002). On the determinants of foreign direct investment to developing countries: is Africa different?. World Development, 30(1), 107-119. https://doi.org/10.1016/S0305-750X(01)00100-0

Asongu, S. A., Folarin, E. O., \& Biekpe, N., (2019). The Stability of Demand for Money in the Proposed Southern African Monetary Union. International Journal of Emerging Markets. DOI: 10.1108/IJOEM-08-2018-0443.

Bölük, G., \& Mert, M. (2015). The renewable energy, growth and environmental Kuznets curve in Turkey: An ARDL approach. Renewable and Sustainable Energy Reviews, 52, 587-595. https://doi.org/10.1016/j.rser.2015.07.138

Box, G. E., Jenkins, G. M., Reinsel, G. C., \& Ljung, G. M. (2015). Time series analysis: forecasting and control. John Wiley \& Sons.

David, R. (1817). On the principles of political economy and taxation. publicado en.

Dickey, D. A., \& Fuller, W. A. (1981). Likelihood ratio statistics for autoregressive time series with a unit root. Econometrica: Journal of the Econometric Society, 1057-1072. doi: 10.2307/1912517

Dix-Carneiro, R., \& Kovak, B. K. (2017). Trade liberalization and regional dynamics. American Economic Review, 107(10), 2908-46. doi: 10.1257/aer.20161214

Ekpo, A. H. (1995). Openness and economic performance in Nigeria: A time series approach. In Selected Paper for the 1995 Annual Conference The Nigerian Economic Society.

Enders, W. (1995). Applied econometric time series, 1sd New York, Ed. John Willey \& Sons, Inc, 251-276.

Estevadeordal, A., \& Taylor, A. M. (2013). Is the Washington consensus dead? Growth, openness, and the great liberalization, 1970s-2000s. Review of Economics and Statistics, 95(5), 1669-1690. https://doi.org/10.1162/REST a 00358

Greenaway, D., Morgan, W., \& Wright, P. (2002). Trade liberalization and growth in developing countries. Journal of development economics, 67(1), 229-244. https://doi.org/10.1016/S0304-3878(01)00185-7

Haseeb, M., Abidin, I. S. Z., Hye, Q. M. A., \& Hartani, N. H. (2018). The impact of renewable energy on economic well-being of Malaysia: Fresh evidence from autoregressive distributed lag bound testing approach. International Journal of Energy Economics and Policy, 9(1), 269-275. doi: https://doi.org/10.32479/ijeep.7229

Hutchison, T. (1976). Adam Smith and the wealth of nations. The Journal of Law and Economics, 19(3), 507-528. https://doi.org/10.1086/466885

Kee, H. L., Neagu, C., \& Nicita, A. (2013). Is protectionism on the rise? Assessing national trade policies during the crisis of 2008. Review of Economics and Statistics, 95(1), 342-346. https://doi.org/10.1162/REST a 00241

Krugman, P. R. (1987). Is free trade passé?. Journal of Economic Perspectives, 1(2), 131-144. doi: 10.1257/jep.1.2.131

Melitz, M. J., \& Trefler, D. (2012). Gains from trade when firms matter. Journal of Economic Perspectives, 26(2), 91-118. doi:10.1257/jep.26.2.91

Nwaka, I. D., \& Onifade, S. T. (2015). Government Size, Openness, and Income Risk Nexus: New Evidence from Some African Countries (No. WP/15/056). AGDI Working Paper. Available at: https://econpapers.repec.org/RePEc:abh:wpaper:15/056

Oladipo, O. S. (1998). Trade Liberalisation and Economic Growth. Ife Social Science Review, 15(1), 80.

Olatunji, L. A., \& Shahid, M. S. (2015). FDI and Economic Growth in Nigeria: A Co-integration Analysis. Business and Economic Research, 5(1), 243-261. https://doi.org/10.5296/ber.v5i1.6647

Olokoyo, F. O. (2012). Foreign direct investment and economic growth: A case of Nigeria. Journal of Management Research, 4(1), 1-20. http://eprints.covenantuniversity.edu.ng/id/eprint/8989

Olomola, P. A. (1998). Openness and long-run economic growth in Nigeria (1960-98). Journal of Economic Management, $5(1), 39-62$.

Olufemi, S. M. (2004). Trade openness and economic growth in Nigeria: Further evidence on the causality issue. South African Journal of Economic and Management Sciences, 7(2), 299-315. https://hdl.handle.net/10520/EJC31437 
Onifade, S. T., Ay, A., Asongu, S., \& Bekun, F. V. (2020a). Revisiting the trade and unemployment nexus: Empirical evidence from the Nigerian economy. Journal of Public Affairs, e2053. doi.org/10.1002/pa.2053

Onifade, S. T., Çevik, S., Erdoğan, S., Asongu, S., \& Bekun, F. V. (2020b). An empirical retrospect of the impacts of government expenditures on economic growth: new evidence from the Nigerian economy. Journal of Economic Structures, 9(1), 6. https://doi.org/10.1186/s40008-020-0186-7

Pesaran, M. H., \& Shin, Y. (1998). An autoregressive distributed lag modeling approach to cointegration analysis. Econometric Society Monographs, 31, 371-413.

Pesaran, M. H., Shin, Y., \& Smith, R. J. (2001). Bounds testing approaches to the analysis of level relationships. Journal of applied econometrics, 16(3), 289-326. https://doi.org/10.1002/jae.616

Phillips, P. C., \& Perron, P. (1988). Testing for a unit root in time series regression. Biometrika, 75(2), $335-346$. https://doi.org/10.1093/biomet/75.2.335

Prebisch, R. (1950). The economic development of Latin America and it principal problems. Economic Bulletin for Latin America, 7(1), 385-421.

Rodrik, D. (2018). What do trade agreements really do?. Journal of economic perspectives, 32(2), 73-90. doi:10.1257/jep.32.2.73

Rodrik, D. (1997). Trade strategy, investment, and exports: another look at East Asia. Pacific Economic Review, 2(1), 124. https://doi.org/10.1111/1468-0106.t01-1-00020

Shrestha, M. B., \& Bhatta, G. R. (2018). Selecting appropriate methodological framework for time series data analysis. The Journal of Finance and Data Science, 4(2), 71-89. https://doi.org/10.1016/j.jfds.2017.11.001

Smith, A. (1950). An Inquiry into the Nature and Causes of the Wealth of Nations, (1776).

Sulaymonov, A. (2017). Privileges of Free Trade, Factors, and Arguments towards Protectionism. International Journal of Economics and Management Science, 6, 426. doi: 10.4172/2162-6359.1000426.

Taiwo, S., Alagöz, M., \& Erdoğan, S. (2020). Inflation, oil revenue, and monetary policy mix in an oil-dependent economy: empirical insights from the case of Nigeria. International Journal of Business, 7(2), 96-109. doi: 10.18488/journal.62.2020.72.96.109

United Nations Conference on Trade and Development, UNCTAD. (2019). World Investment Report. Geneva: United Nations. Available at https://unctad.org

World Development Indicator, WDI (2018). World Bank, Washington D. C. available at https://databank.worldbank.org/reports.aspx?source=world-development-indicators.

World Trade Organization, WTO. (2018). World Trade Statistical Review. Available at http://www.wto.org/wtsr18

World Investment Report (06 June 2018) UNCTAD/PRESS/PR/2018/018 Geneva, Switzerland. Available at: https://unctad.org/en/PublicationsLibrary/wir2018 en.pdf

Zahonogo, P. (2016). Trade and economic growth in developing countries: Evidence from sub-Saharan Africa. Journal of African Trade, 3(1-2), 41-56. https://doi.org/10.1016/j.joat.2017.02.001 